\title{
Silage review: Safety considerations during silage making and feeding ${ }^{1}$
}

\author{
Keith K. Bolsen ${ }^{*}{ }^{2}$ \\ *Department of Animal Sciences and Industry, Kansas State University, Manhattan 66502 \\ †Keith Bolsen Silage Safety Foundation, 6106 Tasajillo Trail, Austin, TX 78739
}

\begin{abstract}
Silage-related injury knows no age boundary as workers and bystanders of all ages have been killed in silage accidents. Even the best employee can become frustrated with malfunctioning equipment and poor weather conditions and take a hazardous shortcut, or misjudge a situation and take a risky action. At least 6 hazards are encountered in managing silage in bunker silos and drive-over piles that endanger lives: tractor or truck rollover, run-over by or entanglement in machinery, fall from height, crushing by an avalanche or collapsing silage, silage gases, and complacency or fatigue. These hazards are presented in detail along with accounts of 14 individual case studies involving several of them. Guidelines that can dramatically reduce the risk of serious injuries or fatalities from each of the hazards are presented. Every farm, feedlot, dairy, and silage contractor should have written safety policies and procedures for their silage program, and they should schedule regular meetings with all their employees to discuss and demonstrate safety. The most important goal in every silage program is to send all employees home safely to their families at the end of the day.
\end{abstract}

Key words: silage, safety, avalanche, fatality

\section{INTRODUCTION}

Few farming operations invite as many different opportunities for injury or fatality as a silage program (Murphy, 1994). From 2015 to 2017, an average of 115.31 million metric tonnes of whole-plant corn silage was produced annually in the United States (USDA, 2018). Beginning with harvesting the forage in the field, followed by transportation to the farm and placement into storage, as well as subsequent feed-out of the silage, employees in every silage program are exposed to numerous serious risks.

Silage-related tragedy knows no age boundary as workers and bystanders of all ages have been injured or

Received August 25, 2017.

Accepted November 14, 2017.

${ }^{1}$ This article is part of a special issue on silage management.

${ }^{2}$ Corresponding author: keithbolsen@hotmail.com killed during silage harvest and feed-out (Murphy and Harshman, 2006). Although silage injury statistics are not easily collated, countless stories are told of power takeoff and harvesting machine entanglements, highway mishaps between farm equipment and automobiles, entanglements in self-unloading wagons and blowers, as well as encounters with silo gas. Increasingly, stories involve bunker silos and drive-over piles (Bolsen and Bolsen, 2012, 2013, 2015b) as silage utilizing operations become larger due to industry consolidation.

Consistently protecting employees, equipment, and property throughout harvesting, filling, and feeding does not occur without thought, preparation, and training. The silage industry has nothing to lose by practicing safety, but it has everything to lose by not practicing it (Murphy, 2007).

The objective of this paper is to present 6 hazards encountered in managing silage in bunker silos and drive-over piles coupled with detailed accounts of case studies involving the hazards. The primary ways these hazards can be avoided are discussed.

\section{HAZARD 1: TRACTOR OR TRUCK ROLLOVER}

Historically, tractor rollovers have accounted for about $50 \%$ of the approximately 250 tractor-related fatalities reported annually in the United States (National Institute for Occupational Safety and Health, 2004; Figure 1). Management practices that minimize the risk of tractor rollovers include the following:

(1) Rollover protective structures create a zone of protection around the tractor operator. When used with a seat belt, rollover protective structures prevent the operator from being thrown from the protective zone and crushed by the tractor or equipment drawn by it.

(2) A straight drop off a bunker silo wall is a significant risk, so never fill higher than the top of the wall.

(3) Sight rails should be installed on above-ground walls. These rails indicate the location of the wall to the tractor operator, but they are not intended to hold an over-turning tractor. 
(4) Install lights to the rail if filling will occur at night.

(5) When filling bunker silos and drive-over piles, pack tractor operators should always form a progressive wedge of forage, which provides a minimum slope of 1 to 3 for packing (e.g., 1 unit of rise for each 3 units of run).

(6) To reduce the risk of a tractor rollover, it is important to maintain a minimum slope of 1 to 3 on the sides and ends of a drive-over pile.

(7) Tractors should be backed up steep slopes to prevent roll backs.

(8) Use low-clearance, wide-front-end tractors equipped with well-lugged tires to prevent slipping.

(9) Add wheel weights and weights to the front and back of the tractors to improve stability.

(10) Never use large rectangular or round hay or straw bales for temporary bunker walls.

(11) When using front-end loaders to move forage to the bunker or pile, do not elevate the bucket any higher than necessary, thereby helping to keep the center of gravity low.

(12) When 2 or more pack tractors are used, establish a driving procedure to prevent collisions.

Large-scale beef and dairy operations and silage contractors typically use trucks for transporting chopped forage to the bunker or pile (Murphy and Harshman, 2006). Management practices that minimize the risk of a truck accident include the following:

(1) Trucks can overturn on steep forage slopes, particularly if the forage is not loaded and packed uniformly.

(2) Raise the dump body only while the truck is on a firm surface to prevent an overturn.

(3) As the bed is raised for unloading, it is important that the load center of gravity stay between the frame rails of the truck frame.

(4) Trucks are less stable as the bed is raised, particularly if the surface is not perfectly flat.

(5) A tire rut or depression from a previous load, low tires on one side of a truck, uneven loading of a truck, or a wind gust increase the risk of a truck tipping over during unloading, especially when 2 or more of these hazards combine at a single time point.

\section{Case Study 1}

A teenage boy and an older man were unloading sweet corn silage from the back of a tandem axle truck on a farm in Minnesota (cited by Bolsen and Bolsen,
2017). As the box of the truck was raised, the load suddenly emptied and trapped both individuals under the silage. The older man managed to free himself, but the teenager was found unconscious beneath the silage. The boy was pronounced dead a short time later at the hospital.

\section{HAZARD 2: RUN-OVER BY OR ENTANGLEMENT IN MACHINERY}

\section{Case Study 2}

The 29-yr-old son of a Nebraska silage contractor was talking with an employee who was in the cab of a large forage harvester near the edge of a field (Beatrice Daily Sun, 2008). The employee, who thought the contractor's son had left the area, drove the machine out of the field. A few minutes later, another employee found the contractor's son lying unconscious in the field, and he died $2 \mathrm{~h}$ later in the hospital. Although the details surrounding the fatal accident are unclear, the son appeared to have been run over by a rear tire of the forage harvester.

Guidelines that promote safe harvesting practices and prevent serious injuries and fatalities caused by being crushed or entangled in machinery include (adapted from Murphy and Harshman, 2006):

(1) Keep machine guards and shields in place to protect the operator from an assortment of rotating shaft, chain, and V-belt drives; gears and pulleys; and rotating knives on forage harvesters, wagons, and silage feeding equipment.

(2) Keep nonworkers away from traffic areas.

(3) Never allow people on foot (especially children) near the moving harvest and transport equipment in the field or people on foot near a bunker silo or drive-over pile during filling or feed-out.

(4) Adjust rear-view mirrors.

(5) When inspection or servicing work is needed, shut down the engine and remove and pocket the keys to prevent accidental starting by another person.

(6) Mount and dismount the tractor or forage harvester using a debris-free access ladder and steps and handholds. Maintain a 3-point contact as you climb and always face the machine.

(7) Stop the machine before lubricating, adjusting, inspecting, or unplugging. Wait for the cutter head to come to a complete stop before adjusting or unplugging.

(8) Never approach the blades of a silage defacer while the machine is in operation.

(9) Wear snug clothing. 

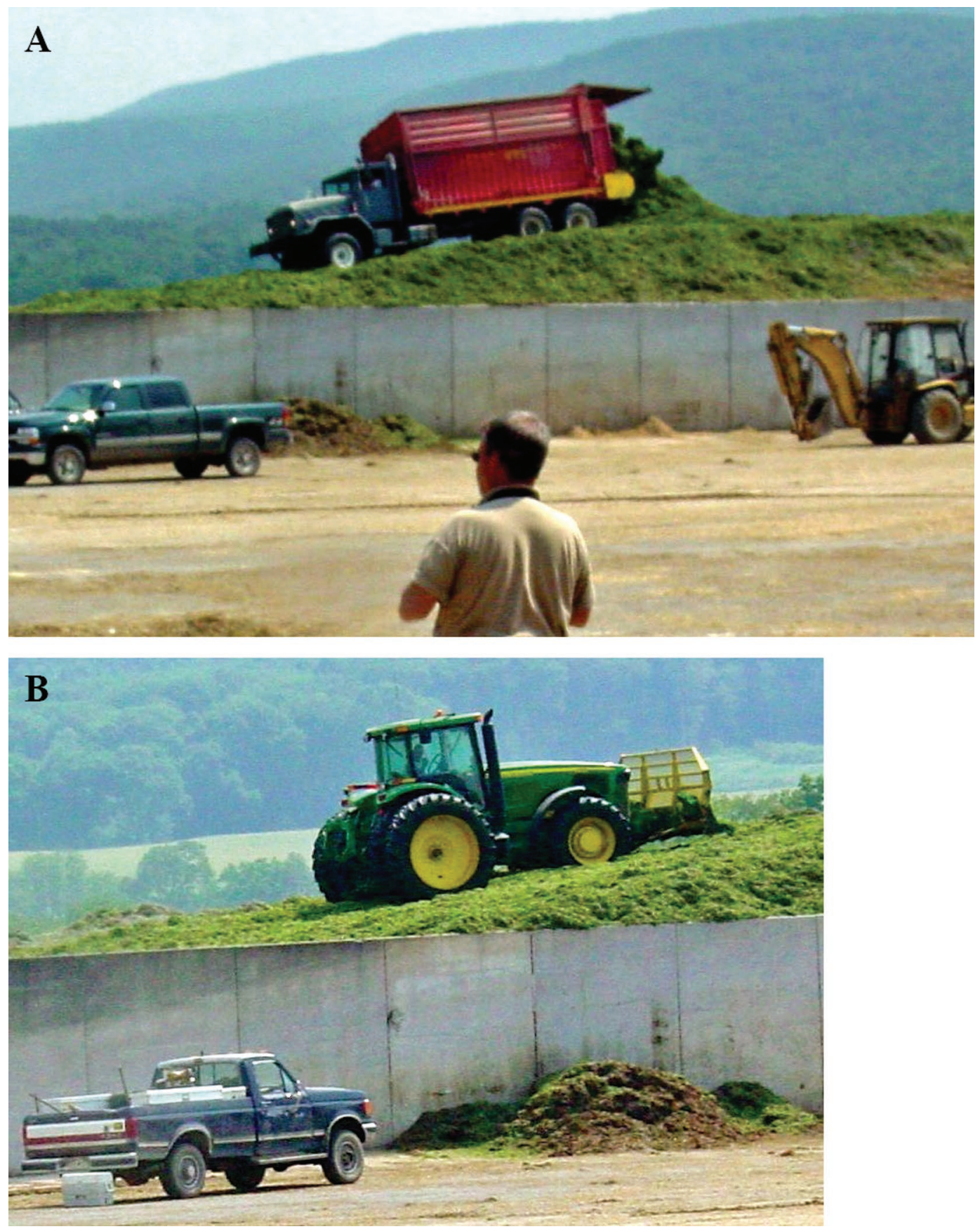

Figure 1. Silage truck (A) and packing tractor (B) operators in dangerous positions above the wall in a bunker silo being filled with fieldwilted alfalfa. Color version available online.

(10) Use reverse alarm devices or a remote video camera on large or oversized machines to increase visibility and warn others that you are operating the equipment in a reverse direction.

(11) Use standard agricultural hand signals to communicate with others when operating machinery or when helping with machinery movement.
(12) Monitor weather and field conditions as they relate to safety and adjust the harvest accordingly.

(13) Be sure all equipment operators are competent and trained for the jobs they are doing.

(14) Employers should remind forage harvester, truck, and tractor operators to be careful, use seat belts, and never take unnecessary risks. The 
reminder should be made at the beginning of every working day.

Following these well-known safety practices lowers the risk that someone will be injured during silage harvesting and ensiling activities. These practices relate primarily to behavioral actions that can be taken by employees and are largely intuitive to experienced farm workers. One reason it is important to articulate these practices is because injury-related data from silage making suggest that many employees do not consistently follow these recommended safety practices.

\section{HAZARD 3: FALL FROM HEIGHT}

Many bunker silos and drive-over piles are too large to be safe for the persons filling them, and for those subsequently loading the ensiled feed for livestock. Trends toward larger livestock units have resulted in greater amounts of silage being stored in outdated and inadequate storage capacity bunker silos. Unless new silos are built, the footprint of drive-over piles enlarged, or packing density increased significantly, there is nowhere for additional silage to be stored but in bunkers or piles of ever-increasing height.

\section{Case Study 3}

A young farmer in Scotland has been reliving the horrific moment that he saw his 62 -yr-old father plunge to his death from the top of a silage pit (Daily Record, 2014). The father and son were pulling back the plastic covering sheets on the top of grass silage when the accident happened. The father's feet got tangled in the plastic, and he fell about $4 \mathrm{~m}$ to the floor of the silo.

Guidelines that can prevent serious injuries and fatalities from a fall from height include the following:

(1) Install standard guardrails on all above-groundlevel walls.

(2) Use caution when removing plastic, oxygenbarrier film, tires, tire sidewalls, or gravel bags from the surface of bunkers and piles, and wear a safety harness tethered with a heavy rope or cable.

(3) When on the top of a bunker or pile, never stand closer to the edge of the feed-out face than the height of the silage.

(4) Use equipment operating from the ground level to remove spoiled silage from the surface of a bunker or pile.

(5) Never allow a person to ride in a front-end loader bucket.

\section{HAZARD 4: CRUSHED BY AN AVALANCHE OR COLLAPSING SILAGE}

It only takes a fraction of a second for part of an exposed silage feed-out face to break off silently and fall, without prior warning. The result can be deadly for anyone beneath. Feed-out faces are unstable, and avalanches cannot be predicted in advance (Holin, 2010a; Figure 2).

Several fatalities have occurred in the United States during the past decade, including a 30-yr-old truck driver on a dairy farm in Idaho, a 53-yr-old employee on a dairy farm in Pennsylvania, and a 54-yr-old employee on a dairy farm in Connecticut (Bolsen and Bolsen, 2014; Daily Mail, 2015). Although rarely reported, stories are common about farm workers or bystanders having a near-miss incident or being injured in a silage avalanche.

\section{Case Study 4}

Six tons of alfalfa haylage in a bunker silo collapsed on a Wisconsin dairy farmer. He was standing $2.5 \mathrm{~m}$ from the feed-out face that was about $3.5 \mathrm{~m}$ tall. The dairyman was rescued in a matter of minutes. However, he suffered a C6 spinal cord injury, which classified him as a quadriplegic (cited by Bolsen and Bolsen, 2017).

\section{Case Study 5}

It started out as a typical day for a dairy nutritionist in California (Holin, 2010b). He pulled up to a client's corn silage pile to take a forage sample, bucket and pitchfork in hand. After filling the bucket, he turned to walk back to his pickup to mix the sample. In less than a second the entire silage face fell on him ... about $16,000 \mathrm{~kg}$ broke away. The nutritionist indicated that this particular pile did not look unsafe at all. It was only 3.4 to $3.6 \mathrm{~m}$ tall, and it was mechanically shaven. The nutritionist had taken samples from piles that were not safe, but he had taken the risk. He stated that the pile looked safe from any angle he looked at it.

\section{Case Study 6}

An 11-yr-old boy died from injuries suffered after a silage face collapsed on him in a bunker silo on a dairy farm in New Hampshire (cited by Bolsen and Bolsen, 2015a). Police said it took about $20 \mathrm{~min}$ to find and free the boy from the silage after the avalanche. The boy was alone in the bunker silo, and no one saw what happened. The feed-out face was about $7.5 \mathrm{~m}$ high, and when the silage was removed, an overhang had been created. 


\section{Case Study 7}

A 19-yr-old man was shoveling silage into a feeder on his family's dairy farm in New York when part of the silage face collapsed on him (cited by Bolsen and
Bolsen, 2017). The feed-out face was about $3 \mathrm{~m}$ high, and the young man was buried under about $1.2 \mathrm{~m}$ of the wet, heavy silage. He was found unconscious by a family member and taken by ambulance to the hospital where he was pronounced dead.
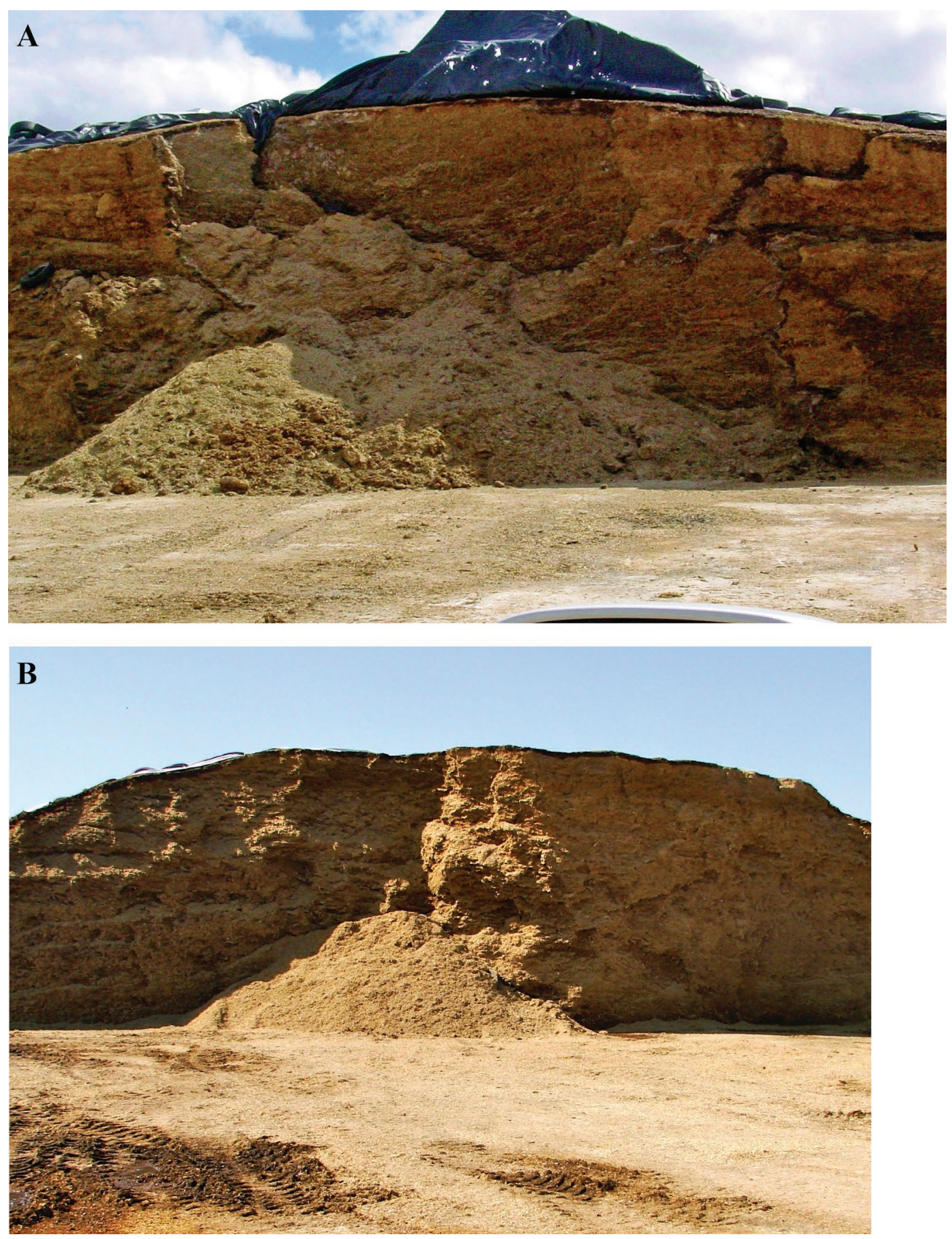

Figure 2. The 2 photos were taken just minutes after the avalanches occurred in a bunker silo (A) and drive-over pile (B). Color version available online. 


\section{Case Study 8}

A 53-yr-old man died in a feedlot accident in Nebraska after being buried by a silage avalanche (cited by Bolsen and Bolsen, 2017). A coworker was seriously injured. The victim was standing in front of the silage face, which was about $4 \mathrm{~m}$ high, and the avalanche pushed the falling silage more than twice that distance from the feed-out face.

\section{Case Study 9}

A 34-yr-old farm employee was working in a bunker silo when a massive amount (about 9,000 to 13,600 $\mathrm{kg}$ ) of corn silage collapsed on him (cited by Bolsen and Bolsen, 2015a). His body was not recovered from the silage until about $3 \mathrm{~h}$ later, and it was determined that he died of mechanical asphyxia. A sample bag was found near his left hip. The man was clutching silage in his hands and had silage in his mouth, which suggested that he struggled to survive in the final moments of his life.

Guidelines to decrease the risk of serious accidents or fatalities caused by a silage avalanche have been formulated (Bolsen et al., 2016). The important principles are (1) avoid excess height when filling bunker silos and building drive-over piles, and (2) avoid working close to the unstable exposed feed-out face. The specific guidelines are as follows:

(1) Bunker silos and drive-over piles should not be filled higher than the loading equipment can reach safely. Typically, a loader can reach a height of 3.5 to $4 \mathrm{~m}$ (Figure 3). Spreadsheet software is available to assist in the design of safe and efficient bunker silos and drive-over piles (https://fyi.uwex.edu/forage/harvest/).

(2) Never allow people to approach the feed-out face.

(3) Never stand closer to the feed-out face than 3 times its height.

(4) Suffocation is a primary concern and a likely cause of death in many silage avalanches, so follow the "buddy rule" and never work alone in a bunker or pile.

(5) Never drive the loader parallel to and in close proximity of the feed-out face in an overfilled bunker or pile (Figure 3).

(6) When removing plastic, oxygen-barrier film, tires, tire sidewalls, or gravel bags from an overfilled bunker or pile, use caution, wear a safety harness, and be tethered with a heavy rope or cable.
(7) Do not work or stand closer to the top edge of the feed-out face than its height.

(8) Do not discard surface spoiled silage. It is simply too dangerous to remove spoilage from the top of many bunkers and piles.

(9) Never park vehicles or equipment near the feedout face.

(10) Take samples from a loader bucket after it is moved to a safe distance from the feed-out face.

(11) Use proper unloading technique that includes shaving silage down the feed-out face and never dig the loader bucket into the bottom of the silage. Undercutting is a situation that is quite common when the loader bucket cannot reach the top of an overfilled bunker or pile.

(12) Post warning signs around the perimeter of bunkers and piles saying, "Danger! Silage Face Might Collapse."

(13) If a silo or pile is in a remote area, the perimeter should be fenced and a sign posted: "Danger: Do Not Enter. Authorized Personnel Only."

\section{HAZARD 5: SILAGE GASES}

Numerous gases, including nitric oxide and carbon dioxide, are produced during the first 2 to 3 wk of harvesting, filling, and ensiling. Silage gases can accumulate in silos, feed rooms, or livestock housing areas and can be fatal to humans and animals alike. Nitric oxide changes to $\mathrm{NO}_{2}$ when it contacts oxygen in the air. Nitrogen dioxide is a toxic gas and can produce a sudden death (Bolsen and Bolsen, 2015a). Even a brief exposure to $\mathrm{NO}_{2}$ can be fatal. Nitrogen dioxide is a reddish-orange to yellowish-brown color heavier than air gas, and smells like laundry bleach. The highest levels of $\mathrm{NO}_{2}$ are usually present during the first 24 to $72 \mathrm{~h}$ after the forage is put into the silo, but dangerous levels can persist for up to $3 \mathrm{wk}$.

When inhaled, $\mathrm{NO}_{2}$ dissolves in the moisture on the internal lung surfaces to form nitric acid. This strong acid burns the pulmonary membrane tissue, effectively stopping the supply of oxygen to the body. Depending on the $\mathrm{NO}_{2}$ concentration, the presence of this silo gas might be recognized by a burning sensation in the nose, throat, and chest. Exposure to high concentrations of $\mathrm{NO}_{2}$ can cause death within minutes, and the victim would not likely have time to detect respiratory symptoms. Exposure to low or moderate concentrations of $\mathrm{NO}_{2}$ can cause permanent lung damage and pneumonia. Even small periodic doses of $\mathrm{NO}_{2}$, such as those that result from working every day in a poorly ventilated feed room located near the bottom of a tower silo chute, can lead to chronic respiratory problems, 

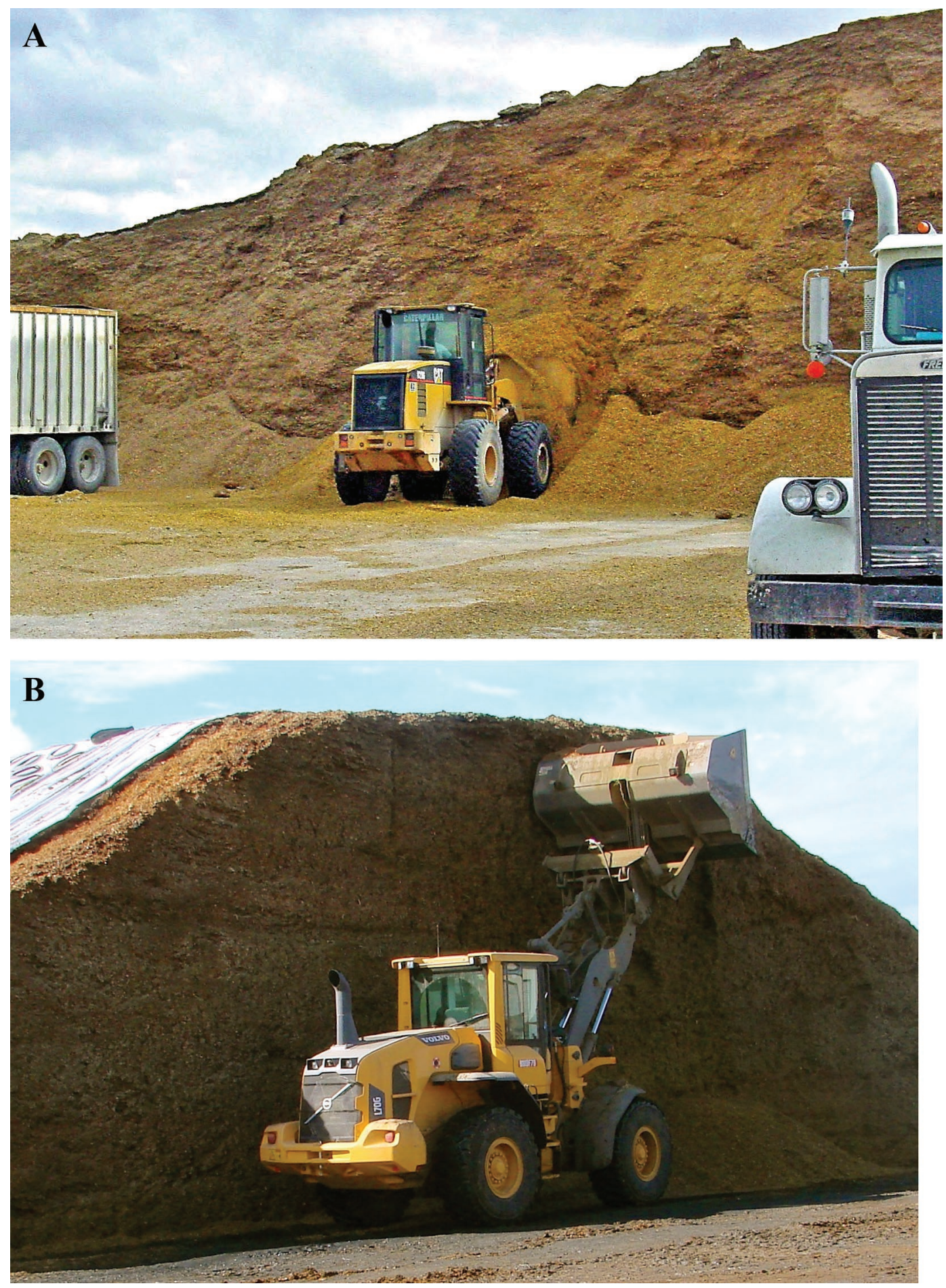

Figure 3. Payloader operator removing corn silage from overfilled bunker silo (A) and driving parallel to the feed-out face in an overfilled pile (B). Color version available online.

including shortness of breath, coughing, and fluid in the lungs. Nitrogen dioxide deadens the sense of smell, and therefore can lead to a false sense that the gas has dissipated when it might still be present in high concentrations. Remember, $\mathrm{NO}_{2}$ does not give a second chance!

Carbon dioxide is odorless, colorless, and tasteless, and it can be dangerous in a closed environment. When 
$\mathrm{CO}_{2}$ reaches a certain concentration in the bloodstream, it triggers a nervous impulse that causes the victim to gasp for air. At higher concentrations, this reflex action is inhibited, and the victim is asphyxiated. Carbon dioxide is particularly hazardous in sealed tower silos, where $\mathrm{CO}_{2}$ replaces oxygen in the headspace. In topunloading silos, $\mathrm{CO}_{2}$ can accumulate at low points on the silage surface. Human survival is completely dependent on a safe external air supply. Do not ignore $\mathrm{CO}_{2}$. It gives very little warning that a person is about to be overcome by a lack of oxygen.

Toxic silage gases are a potential danger to livestock housed close to silos.

\section{Case Study 10}

A cloud of reddish-brown $\mathrm{NO}_{2}$ gas was noticed escaping from underneath the plastic sheet on a bunker silo of corn silage on a dairy farm in the Netherlands (Verhoeff et al., 2007). The gas entered a cubicle house for dairy cows $1 \mathrm{~d}$ after ensiling. Eleven cows developed dyspnea (difficult or labored breathing), and 3 of them subsequently died. The cause of the accident was attributed to a combination of weather conditions, an insufficient sand load on the plastic sheet, and the close proximity of the silo to the cubicle house.

The following guidelines reduce the dangers associated with silage gases:

(1) Properly adjust the distributor/spreader so the forage will be evenly distributed in tower silos and will not require anyone to enter during or after filling.

(2) Beware of yellowish-brown fumes or bleach-like odors at the base of a silo. Stay clear of the silo for at least 3 wk after filling.

(3) Post silo gas warning signs at the base of the silo chute and entrance to the feed room.

(4) Keep children and visitors away from the silo area during the 3 -wk danger period.

(5) Ventilate the feed room with open windows and fans during the danger period. Keep doors between the silo feed room and livestock housing area closed tightly.

(6) If it is necessary to enter a silo at the completion of filling or within 3 wk after filling, ventilate the silo by running the forage blower for at least 30 min with the door closest to the top of the silo open so the gases can escape. Always wear an approved, self-contained breathing apparatus and be attached to a lifeline to someone outside the silo.
(7) If you should experience even slight throat irritation or coughing around a silo, move into fresh air at once. See your doctor immediately if you suspect that you have been exposed to $\mathrm{NO}_{2}$ gas.

\section{HAZARD 6: COMPLACENCY AND FATIGUE}

Always pay attention to your surroundings, be alert, and avoid distractions. Even the best employee can become frustrated with malfunctioning equipment or poor weather conditions and take a hazardous shortcut, or misjudge a situation and take a risky action (Murphy, 1994).

\section{Case Study 11}

A nutritionist almost lost his life taking samples from a bunker silo with a 7-m feed-out face on a dairy farm in Texas. Even though he was standing $6 \mathrm{~m}$ from the face, $10,884 \mathrm{~kg}$ of silage collapsed on him. He did not see or hear anything. He had been in silage pits hundreds of times and had become complacent because nothing ever happened. It just took one time (Schoonmaker, 2000).

\section{Case Study 12}

A nutritionist in Colorado had the following near miss: "I was taking a core sample at one of our large dairy customers, and had just moved away from the face when a large section just fell off. This was a wellpacked silage and face management was immaculate" (cited by Bolsen and Bolsen, 2015a).

\section{Case Study 13}

At a Pennsylvania State University Forage Focus seminar, several farmers told of close calls while shaving bunker or pile feed-out faces that seemed safe but collapsed quickly (Hay and Forage Grower, 2010). One told of the death of a worker while pulling samples: "All three workers went up to the face and they pulled a sample, turned to walk away and the pile just fell away. It hit ... two people from the back and knocked them down. The other guy was walking toward the loader and it completely covered him up. We are still having a hard time dealing with that." After the accident, the farm developed a safety plan. "Our policy is that nobody is allowed closer to the bunker face than the height of the bunker wall. No exceptions. If there is a tire there, we will get it later. If there is a forage sample, you better take it with a bucket. We thought that it wasn't an issue, just like everybody else thought 
it wasn't an issue. Then it happened to us. You don't know what a bunker face is like."

\section{Case Study 14}

"The accident happened late in the afternoon on June 16, 1974, while making wheat silage at Kansas State University's Beef Cattle Research Center. The blower pipe plugged for about the eighth time that afternoon, and I started to dig the forage out from the throat of the blower. The power takeoff shaft was making one more very slow revolution. Zap! The blower blade cut the ends off of three fingers on my right hand." The injured person, Professor Keith Bolsen, said later, "I was mentally tired, physically worn out, and in a hurry. When I pulled my hand from the throat of the blower, I knew immediately that I had done something pretty stupid" (cited by Bolsen and Bolsen, 2017).

Getting people ready for the long hours of silage making is just as important as preparing the equipment for the task (Murphy and Harshman, 2006). Training sessions with all parties involved before the silage season begins can help to refocus the silage team on those tasks that might not have been considered since the previous year. Long harvesting, transporting, filling, and packing hours without periodic breaks and adequate nutrition can increase fatigue, drowsiness, and illness. Here are guidelines that promote a safer work environment:

(1) The silage team should be properly sized to perform all tasks safely.

(2) All employees should get a good night's sleep because tired equipment operators are more likely to make mistakes.

(3) Periodic breaks of 15 to 20 min have proven effective in keeping employees alert.

(4) Rotating work shifts will help keep employees fresh and alert.

(5) Provide nutritious meals for all employees on a regular schedule throughout the day.

(6) Children, pets, and uninformed bystanders should be kept out of the way of the silagemaking operation. They only add distractions to the many responsibilities of the equipment operators.

\section{CONCLUSIONS}

Think safety first! Silage-related injury knows no age boundary as workers and bystanders of all ages have been killed in silage accidents. Even the best employee can become frustrated with malfunctioning equipment and poor weather conditions and take a hazardous shortcut, or misjudge a situation and take a risky action (Murphy, 1994). Only experienced people should operate equipment used to harvest, fill, pack, seal, and feed-out silage. It is best to take steps to eliminate hazards in advance than to rely upon yourself or others to make the correct decision or take the perfect response when a hazard is encountered. The risk of an accident can be dramatically reduced by correctly sizing bunker silos and drive-over piles (Holmes and Bolsen, 2009). Finally, every farm, feedlot, dairy, and silage contractor should have safety policies and procedures for their silage program, and they should schedule regular meetings with all their employees to discuss safety. After all, the most important goal in every silage program is to send all employees home safely to their families at the end of the day.

\section{ACKNOWLEDGMENTS}

The author would like to acknowledge his late parents, Henry and Fay Bolsen of Bement, Illinois, for giving him their encouragement and support to pursue his dream of being a college professor and educator of young men and women. He also thanks the Animal Sciences and Industry Department at Kansas State University for giving him the opportunity to teach and conduct research in the science and practice of cattle nutrition and silage for 32 years. The author will be forever grateful to his wife, Ruthie, for her never-ending love and support of his passion to improve the safety and efficiency of silage programs in the United States and beyond. Finally, this paper is dedicated to the countless victims of silage-related accidents and tragedies that changed lives and families forever.

\section{REFERENCES}

Beatrice Daily Sun. 2008. Family urges safety after fatal farming accident. http://beatricedailysun.com/news/local/family-urges-safety -after-fatal-farming-accident/article_0cd31e86-42d2-59a5-ab7b $-09 \mathrm{~d} 72 \mathrm{~d} 9 \mathrm{~b} 0 \mathrm{f} 9 \mathrm{f} . \mathrm{html}$.

Bolsen, K. K., and R. E. Bolsen. 2012. Three safety issues in largescale bunker silos and drive-over piles in North America. Pages 284-285 in Proc. 16th International Silage Conf., Hameenlinna, Finland. University of Helsinki, Helsinki, Finland.

Bolsen, K. K., and R. E. Bolsen. 2017. Silage Safety 101. Keith Bolsen Silage Safety Foundation, Austin, TX.

Bolsen, R. E., and K. K. Bolsen. 2013. Silage bunkers and piles: A life and death matter. Progressive Forage Grower 14(6):10-11.

Bolsen, R. E., and K. K. Bolsen. 2014. Preventing fatalities and serious injuries from silage avalanches. Pages 66-67 in Progressive Dairyman. Vol. 26, August.

Bolsen, R. E., and K. K. Bolsen. 2015a. Silage safety handbook. Lallemand Animal Nutrition, Milwaukee, WI.

Bolsen, R. E., and K. K. Bolsen. 2015b. Silage safety issues for largescale bunker silos and drive-over piles: avalanches. Pages 301-302 in Proc. 17th International Silage Conf., Piracicaba, Brazil. 
Bolsen, R. E., B. Charley, J. M. Wilkinson, and K. K. Bolsen. 2016. Silage safety practices that save lives. Pages 169-170 in Proc. 17th Int. Forage Conservation Conf. Horny Smokovec, Slovak Republic.

Daily Mail. 2015. Farm worker, 54, dies after getting buried alive in a corn avalanche. http://www.dailymail.co.uk/news/article -3009656/Farm-worker-54-dies-getting-caught-corn-avalanche html\#ixzz3ZBkOVoA0.

Daily Record. 2014. Son tells inquiry of silage pit death plunge. http://www.dailyrecord.co.uk/news/local-news/son-tells-inquiry -silage-pit-3540091.

Hay and Forage Grower. 2010. Producers debate on bunker management. http://hayandforage.com/ecorn-archive/1208-producers -debate-bunker-management/.

Holin, F. 2010a. Handle silage safely. Pages $36-37$ in Hay \& Forage Grower. February.

Holin, F. 2010b. Surviving a silage avalanche. Page 38 in Hay \& Forage Grower. February.

Holmes, B. J., and K. K. Bolsen. 2009. What's new in silage management? Pages $61-76$ in Proc. 15th International Silage Conf., Madison, WI.

Murphy, D. J. 1994. Silo filling safety. Fact sheet E-22. Agric. and Biol. Engineering Dept., The Pennsylvania State University, University Park.
Murphy, D. J. 2007. It's dangerous in those bunkers. Agric. Safety and Health News. Agric. and Biol. Engineering Dept., Vol. 18, No. 2. March/April. The Pennsylvania State University, University Park. Murphy, D. J., and W. C. Harshman. 2006. Harvest and storage safety. Pages 171-187 in Proc. Silage for Dairy Farms: Growing, Harvesting, Storing, and Feeding. NRAES Publ. 181. Ithaca, NY.

National Institute for Occupational Safety and Health. 2004. National Agricultural Tractor Safety Initiative. Swenson, ed. NIOSH Agricultural Safety and Health Centers, Pacific Northwest Agricultural Safety and Health Center, University of Washington, Seattle.

Schoonmaker, K. 2000. Four ways to be safe around silage. Dairy Herd Manage. October 2000.

USDA. 2018. National Agricultural Statistics Service. Corn for silage: 2015-2017. Accessed February 2018. http://usda.mannlib.cornell .edu/usda/current/CropProdSu/CropProdSu-01-12-2018.pdf.

Verhoeff, J., G. Counotte, and D. Hamhuis. 2007. Nitrogen dioxide (silo gas) poisoning in dairy cattle. Tijdschr. Diergeneeskd. 132:780-782. 